\title{
Effect of Diet Containing Palm Kernel Cake and Coconut Meal Cake on Growth Performance and Carcass Quality of Free-Range Chicken in Malaysia \\ (Kesan daripada Diet yang Mengandungi Isirung Kernal Sawit dan Isirung Kelapa pada Prestasi Pertumbuhan dan Kualiti Sembelihan Ayam Lepas Bebas di Malaysia)
}

\author{
M. Mohd Shahmi Hakimi, Z. Alias*, M.M. Rahman, W.E. Wan Khadijah \& R.B. Abdullah
}

\begin{abstract}
Significant increase in feed cost has forced many farmers to identify new alternative sources for free-range chicken diet by using local ingredients to replace imported feeds. This study aim was to evaluate the effect of age and diet containing palm kernel cake (PKC) and coconut meal cake (CMC) on feed intake, growth and carcass quality of free-range chickens in Malaysia. Two hundred crossbred free-range chickens were reared from day old to 12 Weeks of age. At 3 Weeks of age, chickens were divided into 2 dietary treatment groups: Commercial finisher diet (CFD) and formulated finisher diet (FFD) containing CMC and PKC, whereby the body weight and feed intake were measured weekly until the end of the study. The chickens were slaughtered at 9 and 12 Weeks of age. Most data showed no significant difference on growth performance between diets. Male CFD showed higher growth rate than the male FFD diet, while no significant difference was observed on growth rate of female chicken for both diets. Despite that, FFD fed chickens showed no significant different between CFD chickens in term of meat to bone ratio at 12th Week of age, indicating that FFD could result in production meat as good as CFD chickens and produce low undesirable products. In conclusion, CMC and PKC have the potential to be used in FFD as an alternative to CFD for free range chickens.
\end{abstract}

Keywords: Age; crossbred free-range chickens; finisher diet; growth performance; local feed sources

ABSTRAK

Kenaikan kos makanan yang ketara telah memaksa ramai petani mengenal pasti sumber alternatif baru, contohnya, menggunakan ramuan tempatan untuk menggantikan makanan yang diimport. Tujuan kajian ini adalah untuk menilai kesan umur dan diet yang mengandungi isirung kernel sawit (PKC) dan isirung kelapa (CMC) terhadap pengambilan makanan, pertumbuhan dan kualiti karkas ayam kampung di Malaysia. Dua ratus (200) ayam kampung kacukan diternak dari sehari hingga 12 minggu. Pada umur 3 minggu, ayam dibahagikan kepada 2 kumpulan rawatan diet: diet akhir komersial (CFD) dan diet formulasi akhir (FFD) yang mengandungi CMC dan PKC dengan berat badan dan suapan makanan diukur setiap minggu sehingga akhir kajian. Ayam disembelih pada umur 9 dan 12 minggu. Data menunjukkan tiada perbezaan yang signifikan terhadap prestasi pertumbuhan antara diet. Ayam jantan yang diberi makan CFD menunjukkan kadar pertumbuhan yang lebih tinggi daripada diet FFD ayam jantan, sementara tiada perbezaan yang signifikan diperhatikan pada kadar pertumbuhan ayam betina bagi kedua-dua diet. Walaupun begitu, FFD yang diberi kepada ayam menunjukkan tiada perbezaan yang signifikan antara ayam CFD daripada segi nisbah daging hingga tulang pada minggu ke-12, menunjukkan bahawa FFD boleh menghasilkan pengeluaran daging yang baik seperti ayam CFD dan menghasilkan produk yang tidak diingini yang rendah. Sebagai kesimpulan, CMC dan PKC mempunyai potensi untuk digunakan dalam FFD sebagai alternatif kepada CFD untuk ayam kampung.

Kata kunci: Ayam kampung kacukan; diet akhir; prestasi pertumbuhan; sumber makan tempatan; umur

\section{INTRODUCTION}

Free-range chicken is one of the major contributors to supply protein for human consumption, which contributes at least $33 \%$ of the meat consumption around the globe. The global per capita consumption of poultry meat is approximately $13.5 \mathrm{~kg}$, where poultry meat consumption varies among countries was recorded (International Poultry Council 2011). In 2017, there were about 12 million of free-range chickens that were reared in rural areas for meat and eggs in Malaysia (Department of Veterinary Service Malaysia 2017). The annual demand of free-range chickens has increased significantly due to the unique taste preference of the chickens and believed to contains health related benefit of the free-range chicken's meat among the major population of the world. Free range chicken has the potential in term of their nutritive value for the consumers (Oh 1987) and disease resistance capability for the farmers, resulting in the increase in the demand of the commodity. Ariff et al. (2010) reported that in Malaysia, there were approximately 334 tons of free-range chickens exported in $2007,53 \%$ of it were exported to Singapore. This shows that the free-range chicken industry in Malaysia is a viable 
industry, where the rate of return in is almost $88 \%$ within 4 years and the free-range chicken can be sold at premium price, which is $57 \%$ higher compared to the processed commercial broiler (Saonoah 2006). Currently, the poultry population in Malaysia is 308.1 million chickens, whereas in 2016 , the poultry meat self-sufficiency ratio (SSR) is $98.5 \%$ with per capita consumption (PCC) $50.1 \mathrm{~kg} /$ year (Department of Statistic Malaysia 2016). Free-range chickens account for $13 \%$ of total poultry population in Malaysia (Supramaniam 1987) which is assume about 40 million populations in 2016.

It is known that, free-range chicken grows slower and produces lesser number of eggs compared to the commercial chicken. Thus, many researchers conducted various studies to improve the growth performance of the free-range chickens. Engku Azahan et al. (2011) improved the free-range chicken by monitoring their growth phases, where he recorded that the fastest growth of the crossbred free-range chickens was at Weeks 8 to 9. It was found that the body weight (BW), weight gain (WG), feed intake (FI), and carcass evaluation (CE) were most considered by the researchers to determine the growth performance in poultry (Ahmed \& Azahan 2011; Engku Azahan et al. 2011; Khawaja et al. 2007; Kingori et al. 2003). Besides, the growth of chicken is not just only due to the type of strains but also due to the types of the feed given. Engku Azahan et al. (2011) reported that given proximately $11 \mathrm{MJ} / \mathrm{kg}$ of metabolisable energy feed can promote chicken for better growth and give economical advantage for the free-range chicken farmers. Furthermore, most of the commercial feeds are formulated using imported ingredients such as corn, soybean meal and wheat pollard, thus increases the feed cost for the industry. Most of the farmers who rear the free-range chicken are rural farmers, thus the use of commercial feed is an economic burden to them.

Most of the Malaysian rural farmers give local feed resources such as food leftover, spoiled fruits, rice and vegetables to their chicken as feed for replacement to the commercial feed. However, without guidance and lack of knowledge in poultry feed formulation can result in slow growth of free-range chicken. Slow growth of free-range chicken also results in the increase of free-range chicken rearing time and these causes in increment of maintenance cost. Despite that, the use of local alternative ingredients is still preferred to improve the growth performance of free-range chicken and decreases the cost of feed, if it is properly formulated according to the requirement of free-range chicken. Feeding the free-range chicken with balanced feed can boost the performance of the chicken. One of the local sources of feed that can be used for the free-range chicken is palm kernel cake (PKC). The PKC is a good alternative due to its availability and moderate nutritional contents such as crude protein (Alimon 2004; Sharmila et al. 2014). Moreover, meat extracted milk from coconut, coconut meal cake (CMC), also a good alternative to the chicken due their high gross energy content and cheaper (Dzulfazly et al. 2016; Yulvianti et al. 2014). There is little information on potential of PKC and $\mathrm{CMC}$ in free-range chicken's diets. Therefore, this research was carried out to investigate the effect of selected local feed sources (PKC and CMC) on growth performance of freerange chicken.

\section{MATERIALS AND METHODS}

\section{EXPERIMENTAL ANIMALS}

The study was conducted at Livestock Science Centre, Institute of Biological Sciences, University of Malaya for 6 months (from April to October 2016). Two hundred (200) crossbred free-range chickens were reared from a day old to 12 Weeks of age. A day old chicks were reared inside aluminum brooder supplied with 100 watts of bulb and sawdust to provide proper environment for the chicks. All a day-old chicks were vaccinated with Newcastle Disease (ND) and infectious bronchitis (IB) vaccine (ND-IB Vaccine). From a day-old to 21 days of age, the chicks were given starter commercial diet to ensure chicks survival and adaptation to the new feed offered. The study was approved by University of Malaya Institutional Animal Care and Use Committee (UMIACUC) with ethics number I/02022017/03112016-01/R.

\section{DIET FORMULATION}

A diet was formulated using local and imported ingredients with required crude protein $(\mathrm{CP})$ and metabolizable energy (ME) for the chicks. Chemical analyses of feed ingredients were carried out at Malaysian Agricultural Research and Development Institute (MARDI), Selangor, Malaysia (Table 1).

TABLE 1. Chemical composition of formulated feed ingredients

\begin{tabular}{lcc}
\hline Ingredients & $\begin{array}{c}\text { Amount } \\
(\mathrm{Kg})\end{array}$ & $\begin{array}{c}\text { Dry matter } \\
(\mathrm{DM}, \%)\end{array}$ \\
\hline Corn & 29.8 & 87.0 \\
Rice bran & 11.9 & 91.0 \\
Palm kernel cake & 7.4 & 90.6 \\
Coconut meat & 14.1 & 43.0 \\
Soybean meal & 26.0 & 91.0 \\
Vitamin premix & 4.5 & - \\
Mono-dicalcium Phosphate (MDCP) & 4.5 & - \\
Salt & 0.9 & - \\
Limestone & 0.9 & - \\
Total & 100 & - \\
\hline
\end{tabular}

Two hundred (200) day old chicks were reared inside 4 aluminum brooders provided 100 watts of bulb and sawdust to provide a comfortable environment for the chicks. Chicks were divided into 2 groups with mixed genders. The BW of the chickens was measured weekly using 1 $\mathrm{kg}$ weighing balance. Feed intake (FI) was measured on a pen basis to estimate feed conversion ratio of the two dietary treatments, commercial diet which was bought 
from local market and formulated diet. Feed intake was measured weekly by measuring the difference between total amount of feed given and feed residue. At 3 Weeks of age, the chicks were fed commercial and formulated diets for respective groups. All of the chickens were slaughtered at Weeks 8 and 12. The slaughtered chickens were dressed by semi-scald method and the feathers were removed manually in rotary drum picker. The head, crop, lower legs, and viscera were removed. The weight of warm eviscerated carcasses, liver, gizzard, heart and abdominal fat were recorded. Measurement of meat to bone ratio and moisture were done by separating meat from bone for both white and dark meats (Qiao et al. 2001). Subsequently, the fresh meats were placed inside an oven at $98^{\circ} \mathrm{C}$ for $48 \mathrm{~h}$ to dry the samples, after which the dried meats were reweighed. The carcass quality of chickens was compared among diets and ages.

\section{STATISTICAL ANALYSIS}

The data were analyzed using Statistical Package for the Social Science (SPSS) software with Duncan Multiple Range Test (DMRT) for ANOVA on effect of gender and different diet on the growth performance of the free-range chicken.

\section{RESULTS AND DISCUSSION}

One of the major contributors to the performance of chicken is type of diet, which should be contained sufficient amount CP and ME. Approximately 20-22\% of crude protein is preferred for a steady growth of free-range chicken (Mbajiorgu et al. 2011; Mupeta et al. 2000) and ME is approximately $12.0 \mathrm{MJ} / \mathrm{kg}$ DM for growing phase of free-range chicken (NRC 1994; Tadelle et al.2003). In this study, ME for FFD and CFD were 9.84 and $9.36 \mathrm{MJ} / \mathrm{kg} \mathrm{DM}$, respectively. The CP of the FFD diet (14.73\%) was relatively similar to that of CFD diet $(13.40 \%)$. Previous studies indicated the strong relationship between $\mathrm{CP}$ and chicken growth performance, which showed chicken that had been fed with high CP tends to grow faster (Liu et al. 2015). This similar trend was observed in this study. Proximate analysis from the present study showed that CMC had the following values: gross energy (19.41 MJ/kg DM), CP (4.1\%), crude fat $(10.21 \%)$, crude fibre $(34.65 \%)$ and ash $(0.78 \%)$. Since it is easily available and low cost in tropical Malaysia, CMC can be a good consideration as energy source for the local free-range chicken. Besides, PKC also is one of the local feed ingredients, and easily accessible in this country which is a major agriculture industry to produce palm oil. Meanwhile, the present results also showed that PKC had the following values: gross energy $(15.78 \mathrm{MJ} / \mathrm{kg} \mathrm{DM}), \mathrm{CP}$ $(8.13 \%)$, crude fat $(4.43 \%)$, crude fibre $(16.10 \%)$, and ash $(13.15 \%)$. Therefore, it could be suggested that the CMC and PKC in currently a formulated diet that have the potential to replace the expensive commercially formulated feed ingredients (CFD, USD 0.54 vs. FFD, USD 0.36) (Table 2).

From Figure 1, there were no significant differences observed on growth performance up to Week 12 between the two diets, except at Week 10. The significant different showed in Week 10 might be due to the increment factor of weight more prominent for CFD male compared to FFD male at Week 10, by using observation during this period, the size and weight of male birds was increased significantly due to the factors such as feather and bone weight. Meanwhile, the FCR for CFD and FFD diets were 2.40 and 2.57, respectively, which was higher compared to previous study of Engku Azahan et al. (2011) who recorded low FCR (1.9) using the same type of free-range chicken (Table 3). This might be due to the environmental factor and different cross of free-range chicken strains. Factors affecting FCR might be due to the ME, where Engku Azahan et al. (2011) who fed the chicken with diet containing ME a range of 10.5-12.5 $\mathrm{MJ} / \mathrm{kg} \mathrm{DM}$, whereas in this research we used approximately $9-10 \mathrm{MJ} / \mathrm{kg}$ of ME. However, FCR recorded were much lower compared to commercial broiler (3.1), which had been experimented by Liang et al. (1995). In this study, the FCR between free-range chicken fed with CFD and FFD diets did not differ significantly in this study. The cost of FFD diet was calculated to be cheaper up to $33.33 \%$ compared to the cost of CFD diet, indicating that FFD diet could be recommended for economic reason and farming sustainability. This could be due to the local raw materials used (CMC and PKC) in the FFD. The weekly feed intake for CFD and FFD were $446.63 \mathrm{~g} /$ birds and $432.21 \mathrm{~g} /$ birds $(p>0.05)$ from Week 3 until Week 12, respectively. Also, there was no significant difference of average weekly

TABLE 2. Comparison of nutrients composition and approximate local price between commercial diet and formulated diet

\begin{tabular}{lcc}
\hline Nutrients composition & $\begin{array}{c}\text { Commercial finisher } \\
\text { diet (CFD) }\end{array}$ & $\begin{array}{c}\text { Formulated finisher } \\
\text { diet (FFD) }\end{array}$ \\
\hline Dry matter (\%, DM) & 89.05 & 81.16 \\
Crude protein (\%, DM) & 13.40 & 14.95 \\
Crude fat $(\%$, DM) & 3.02 & 3.78 \\
Crude fibre (\%, DM) & 3.12 & 12.22 \\
Ash $(\%$, DM) & 4.43 & 5.18 \\
Gross energy (MJ/kg DM) & 16.30 & 17.13 \\
Metabolizable energy (MJ/kg DM) & 9.36 & 9.84 \\
Approximate local price (USD)/kg & 0.54 & 0.36 \\
\hline
\end{tabular}



types of diet

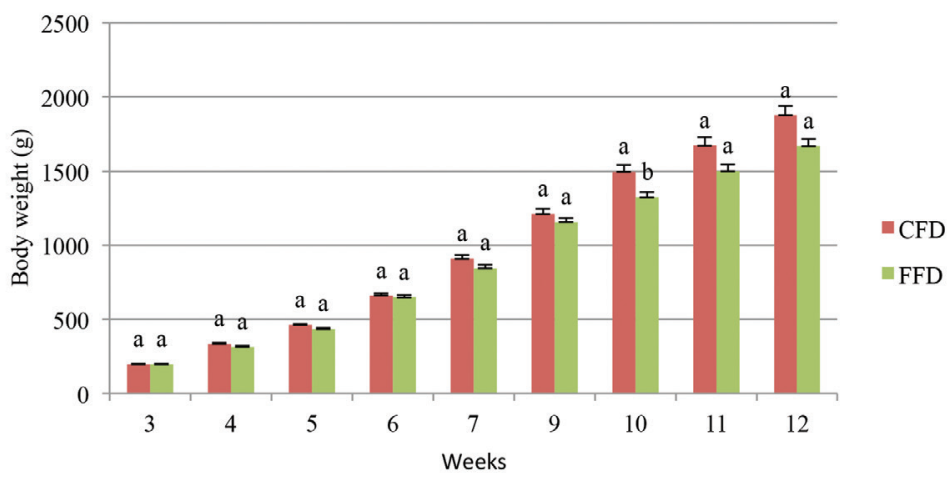

FIGURE 1. Effect of age and diet on growth performance of free-range chickens

weight gains between both diets (CFD, $187.7 \mathrm{~g} / \mathrm{bird}$ vs. FFD, $175.4 \mathrm{~g} /$ bird) as shown in Table 3 . The average daily gains for both diets in this study were lower compared with commercial broiler and higher than indigenous chicken in previous study (Liang et al. 1995). Comparing the growth performance of two strains of free-range chickens, the higher average daily gains in the crossbred free-range chicken compared with indigenous chicken could be due to higher feed intake of the former, thus reflecting the effect of strains and FCR of free-range chicken (Liang et al. 1995; Ramlah 1996).

Effects of age and gender on growth performance of free-range chickens are shown in Table 4. There was no significant difference on BW of chickens between CFD and FFD diets. Despite of having higher $\mathrm{CP}$ and ME shown in Table 2 for mixed gender free-range chicken fed with FFD compared to CFD, the average weekly body weight gains were not significant (Table 3 ). This might be due to uneven nutrient mixture and distribution in the different manually formulated diets prepared daily. As expected, male free-range chickens (CFD, $1018.5 \mathrm{~g}$; FFD, $951.8 \mathrm{~g}$ ) were significantly heavier in average weekly body weight compared to females (CFD, 784.5 g; FFD, 752.0 g) for CFD and FFD diets (Figure 2). As for slaughtered body weight of male chicken at Week 8 and Week 12, CFD diet gave significantly higher values (1018 g/bird and $2491.6 \mathrm{~g} / \mathrm{bird})$ than FFD diet (784.5 g/bird and $1532.5 \mathrm{~g} / \mathrm{bird})$, respectively (Week 8 and Week 12). This could be due to the higher inconsistent manual preparation during the daily feed formulation of FFD as well as unfavourable palatability and digestibility of FFD. As for female chickens, the BW showed no significance different for both diets for Week 8 and Week 12 (Figure 2). The difference could be due to the average feed intake, which was higher for males fed with CFD compared to FFD (Table 3). The carcass evaluation for CFD and FFD fed chickens showed significant differences in weights for carcass, heart, abdominal fat, white meat, and dark meat as well as meat to bone ratio. The differences might be due to the digestibility of local resources such as PKC that had been reported of its low ability for utilizing energy in poultry diets due to their high fiber content (Sharmila et al. 2014), thus resulting in low weight gained for FFD fed chicken. It was reported that the use of PKC in poultry not much affecting the growth performance of chicken despite of nutrient improvement in the diets (Saenphoom et al. 2013). It could be suggested that PKC could be a component of feed formulation for free-range chicken provided that further studies needed in aspects of improving palatability, digestibility and optimum proportion of PKC in the formulated diet. Generally, crossbred free-range chickens are slaughter at 2-3 month of age. The findings from this study showed that at 3 months of age, the ratio of meat to bone for white and dark meat showed no significant difference between CFD (male white meat; $453.5 \mathrm{~g} / \mathrm{bird}$, female white meat; $378.9 \mathrm{~g} / \mathrm{bird}$, male dark meat; $484.1 \mathrm{~g} / \mathrm{bird}$, female dark meat; $317.5 \mathrm{~g} / \mathrm{bird}$ ) and FFD (male white meat; $436.0 \mathrm{~g} /$ bird, female white meat; $349.0 \mathrm{~g} / \mathrm{bird}$, male dark meat; 415.2g/bird, female dark meat; $302.2 \mathrm{~g} / \mathrm{bird}$ ) fed chicken for both genders, respectively. Furthermore, data of meat

TABLE 3. Effect of diets on feed intake and feed conversion ratio in mixed gender of crossbred free-range chicken

\begin{tabular}{lcc}
\hline Parameter & Commercial finisher diet (CFD) & Formulated finisher diet (FFD) \\
\hline Feed intake (Weeks 3-12), (g/chick) & $446.6 \pm 73.3^{\mathrm{a}}$ & $432.2 \pm 70.9^{\mathrm{a}}$ \\
Average weekly weight gained (Weeks 3-12) (g/chick) & $187.7 \pm 22.2^{\mathrm{a}}$ & $175.4 \pm 20.8^{\mathrm{a}}$ \\
Average daily gained (Weeks 3-12) (g/chicks) & $26.8 \pm 3.2^{\mathrm{a}}$ & $25.1 \pm 3.0^{\mathrm{a}}$ \\
Feed conversion ratio/week (FCR) (Weeks 3-12) & $2.4 \pm 0.4^{\mathrm{a}}$ & $2.6 \pm 0.4^{\mathrm{a}}$ \\
\hline
\end{tabular}

${ }^{\mathrm{a}}$, means with the same superscript letter in same row shows no significant difference $(p>0.05)$ 
TABLE 4. Effect of diets on carcass performances between genders of crossbred free-range chickens

\begin{tabular}{|c|c|c|c|c|}
\hline \multirow[t]{2}{*}{ Parameter } & \multicolumn{2}{|c|}{ Commercial diet } & \multicolumn{2}{|c|}{ Formulated diet } \\
\hline & Male $(\mathrm{CM})$ & Female (CF) & Male (FM) & Female (FF) \\
\hline \multicolumn{5}{|l|}{ 8th Weeks age } \\
\hline Live weight & $1718.0 \pm 47.4^{\mathrm{d}}$ & $1260.4 \pm 60.0^{\mathrm{b}}$ & $1408.0 \pm 28.0^{c}$ & $1127.0 \pm 23.4^{\mathrm{a}}$ \\
\hline Carcass weight & $1321.0 \pm 85.6^{\mathrm{c}}$ & $946.0 \pm 39.9^{\mathrm{ab}}$ & $1020.0 \pm 25.9^{b}$ & $815.8 \pm 21.4^{\mathrm{a}}$ \\
\hline Gizzard & $43.0 \pm 0.9^{\mathrm{a}}$ & $35.8 \pm 1.1^{\mathrm{a}}$ & $43.2 \pm 3.7^{\mathrm{a}}$ & $37.0 \pm 4.1^{\mathrm{a}}$ \\
\hline Liver & $42.4 \pm 3.6^{\mathrm{b}}$ & $30.0 \pm 2.7^{\mathrm{a}}$ & $43.2 \pm 1.1^{\mathrm{b}}$ & $32.0 \pm 3.4^{\mathrm{a}}$ \\
\hline Heart & $10.6 \pm 1.5^{b}$ & $6.0 \pm 1.0^{\mathrm{a}}$ & $6.0 \pm 1.0^{\mathrm{a}}$ & $5.0 \pm 0.0^{\mathrm{a}}$ \\
\hline Abdominal fat & $15.6 \pm 4.5^{b}$ & $7.0 \pm 3.1^{\mathrm{ab}}$ & $3.9 \pm 1.8^{\mathrm{a}}$ & $2.1 \pm 0.6^{\mathrm{a}}$ \\
\hline White Meat & $609.5 \pm 22.6^{\mathrm{c}}$ & $429.7 \pm 15.4^{\mathrm{ab}}$ & $462.4 \pm 14.1^{\mathrm{b}}$ & $378.2 \pm 13.9^{\mathrm{a}}$ \\
\hline Dark Meat & $513.2 \pm 24.7^{\mathrm{c}}$ & $358.5 \pm 16.9^{\mathrm{ab}}$ & $407.2 \pm 14.1^{\mathrm{b}}$ & $309.5 \pm 5.4^{\mathrm{a}}$ \\
\hline $\begin{array}{l}\text { Meat to Bone ra } \\
-\quad \text { White meat } \\
-\quad \text { Dark Meat }\end{array}$ & $\begin{array}{c}284.9 \pm 11.5^{\mathrm{b}} \\
261.2 \pm 9.2^{\mathrm{c}}\end{array}$ & $\begin{array}{l}214.0 \pm 5.9^{\mathrm{a}} \\
187.1 \pm 8.9^{\mathrm{ab}}\end{array}$ & $\begin{array}{l}224.2 \pm 11.7^{\mathrm{a}} \\
211.7 \pm 12.5^{\mathrm{b}}\end{array}$ & $\begin{array}{c}192.3 \pm 11.9^{\mathrm{a}} \\
168.6 \pm 1.9^{\mathrm{a}}\end{array}$ \\
\hline \multicolumn{5}{|l|}{ 12th Weeks age } \\
\hline Live weight & $2791.0 \pm 149.9^{b}$ & $2495.0 \pm 88.5^{\mathrm{b}}$ & $1951.0 \pm 116.8^{\mathrm{a}}$ & $1805.0 \pm 43.8^{\mathrm{a}}$ \\
\hline Carcass weight & $2146.0 \pm 109.6^{\mathrm{c}}$ & $1500.0 \pm 78.9^{\mathrm{a}}$ & $1818.0 \pm 83.0^{\mathrm{b}}$ & $1332.0 \pm 32.5^{a}$ \\
\hline Gizzard & $64.4 \pm 1.5^{\mathrm{b}}$ & $56.0 \pm 1.7^{\mathrm{a}}$ & $67.0 \pm 3.1^{\mathrm{b}}$ & $64.6 \pm 2.0^{\mathrm{b}}$ \\
\hline Liver & $51.3 \pm 5.7^{\mathrm{ab}}$ & $36.5 \pm 3.1^{\mathrm{a}}$ & $61.8 \pm 7.7^{\mathrm{b}}$ & $46.3 \pm 6.3^{\mathrm{ab}}$ \\
\hline Heart & $12.7 \pm 1.0^{\mathrm{c}}$ & $7.9 \pm 0.4^{\mathrm{a}}$ & $10.7 \pm 0.7^{b}$ & $7.4 \pm 0.3^{\mathrm{a}}$ \\
\hline Abdominal fat & $31.0 \pm 7.0^{\mathrm{c}}$ & $24.1 \pm 9.7^{\mathrm{bc}}$ & $9.9 \pm 9.5^{\mathrm{b}}$ & $6.5 \pm 6.6^{\mathrm{a}}$ \\
\hline White meat & $1073.7 \pm 56.7^{\mathrm{c}}$ & $806.1 \pm 42.9^{\mathrm{ab}}$ & $940.0 \pm 53.1^{\mathrm{bc}}$ & $715.6 \pm 15.2^{\mathrm{a}}$ \\
\hline Dark meat & $1008.9 \pm 70.6^{c}$ & $648.4 \pm 37.0^{\mathrm{a}}$ & $826.2 \pm 39.1^{\mathrm{b}}$ & $567.9 \pm 19.5^{\mathrm{c}}$ \\
\hline \multicolumn{5}{|c|}{ Meat to bone ratio } \\
\hline - White meat & $453.5 \pm 36.7^{\mathrm{a}}$ & $378.9 \pm 29.4^{\mathrm{a}}$ & $436.0 \pm 48.0^{\mathrm{a}}$ & $349.0 \pm 19.7^{\mathrm{a}}$ \\
\hline - Dark Meat & $484.1 \pm 40.5^{b}$ & $317.5 \pm 19.9^{\mathrm{a}}$ & $415.2 \pm 41.3^{\mathrm{b}}$ & $302.2 \pm 17.7^{\mathrm{a}}$ \\
\hline
\end{tabular}

a,b,c,d Means with the different superscript letters in same row showed significant differences at $(p<0.05)$

\section{Graph of crossbred free-range chickens growth performance against weeks}

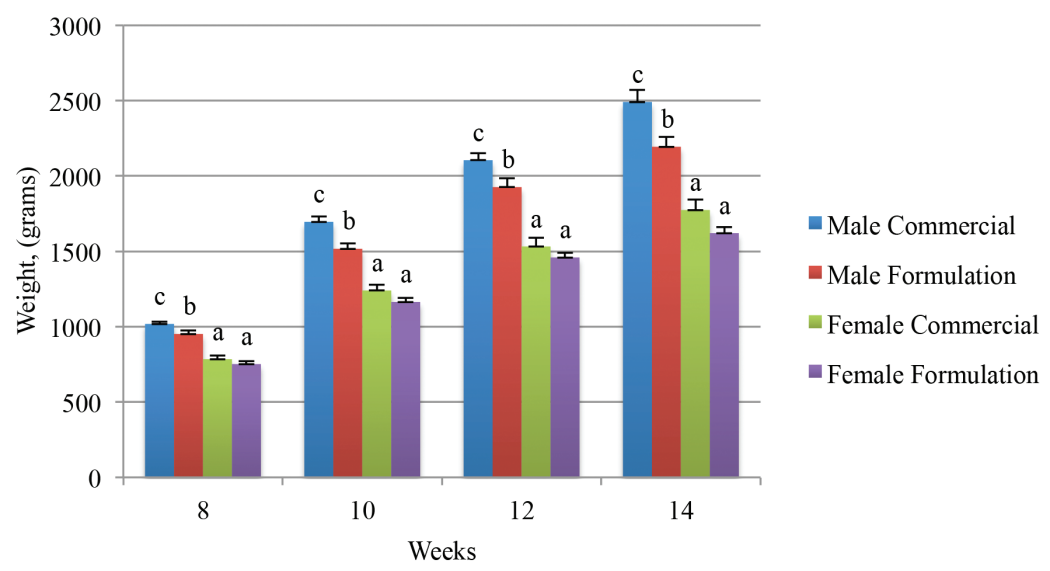

FIGURE 2. Effect of age, gender and diets on growth performance of free-range chickens

to bone ratio (Figure 3) showed significantly increased in meat quantity from Week 8 to Week 12 for CFD and FFD $(236.8 \mathrm{~g}$ and $401.8 \mathrm{~g})$ and $(199.7 \mathrm{~g}$ and $375.6 \mathrm{~g})$.

This may indicate that at this age groups there was improvement in term of meat quantity from Week 8 to Week 12 of age. Besides, Table 4 shows that the data of CFD and FFD have no significant difference in meat to bone ratio despite a significant difference observed for live body weight and carcass evaluation for Week 12. Thus, it could be stated that CFD chickens most develop unprofitable value such as feathers and bone compared to meat which is important as protein source. Moreover, chickens fed with FFD diet (3.9 g/bird and $2.1 \mathrm{~g} / \mathrm{bird})$ for male and female contained significantly lower abdominal fat compared to chickens fed with CFD diet (15.6 g/bird and $7.0 \mathrm{~g} / \mathrm{bird}$ ) for Week 8 and 12, where FFD recorded $(9.9 \mathrm{~g} /$ bird and $6.5 \mathrm{~g} /$ 
Graph of total average meat bone ratio against week

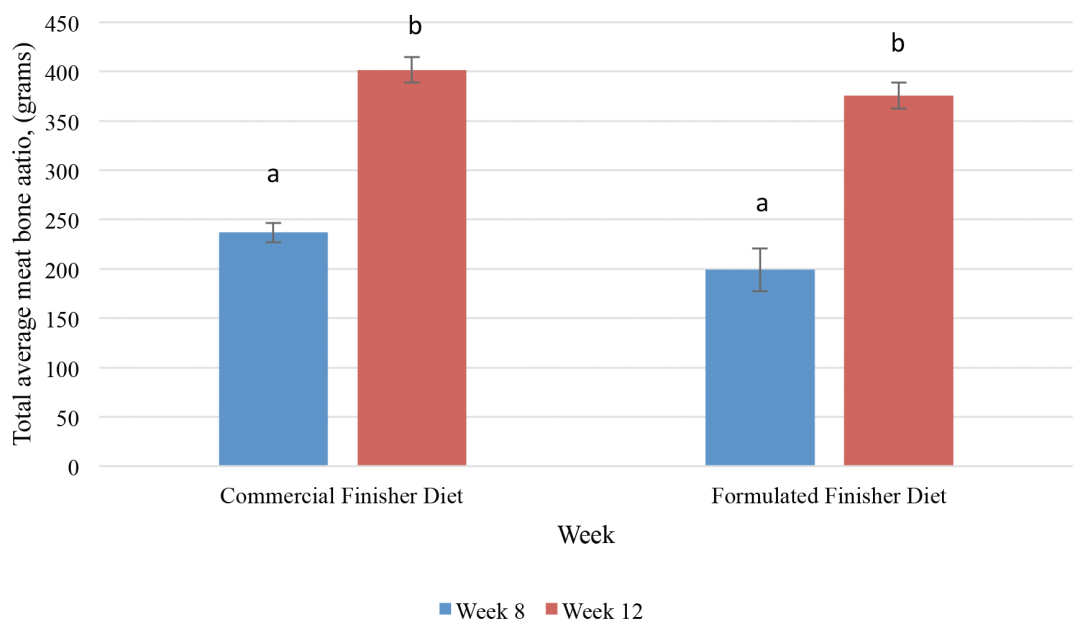

FIGURE 3. Total average meat bone ratio (mixed gender) at slaughtering age

TABLE 5. Cost and profit assumption based on feed intake

\begin{tabular}{|c|c|c|c|c|c|c|c|c|}
\hline \multirow[t]{2}{*}{ Week } & \multicolumn{2}{|c|}{$\begin{array}{l}\text { Daily feed intake } \\
\text { (g/day/bird })\end{array}$} & \multicolumn{2}{|c|}{$\begin{array}{l}\text { Average Live weight } \\
\qquad(\mathrm{g})\end{array}$} & \multicolumn{2}{|c|}{$\begin{array}{c}\text { cost } \\
\text { (USD/Week) } \\
\end{array}$} & \multicolumn{2}{|c|}{$\begin{array}{l}\text { Profit gained } \\
\text { (USD) }\end{array}$} \\
\hline & CFD & FFD & CFD & FFD & CFD & FFD & CFD & FFD \\
\hline 4 & 30.8 & 31.3 & $334.6^{\mathrm{a}}$ & $313.8^{\mathrm{a}}$ & 0.12 & 0.08 & 0.82 & 0.79 \\
\hline 5 & 34.4 & 31.3 & $461.3^{a}$ & $434.7^{\mathrm{a}}$ & 0.13 & 0.08 & 1.16 & 1.14 \\
\hline 6 & 52.8 & 51.0 & $659.7^{\mathrm{a}}$ & $647.4^{\mathrm{a}}$ & 0.20 & 0.13 & 1.65 & 1.68 \\
\hline 7 & 63.5 & 61.6 & $908.3^{\mathrm{a}}$ & $845.5^{\mathrm{a}}$ & 0.24 & 0.16 & 2.30 & 2.21 \\
\hline 9 & 82.3 & 80.8 & $1210.3^{\mathrm{a}}$ & $1155.0^{\mathrm{a}}$ & 0.31 & 0.20 & 3.08 & 3.03 \\
\hline 10 & 84.8 & 80.0 & $1495.9^{\mathrm{a}}$ & $1324.2^{\mathrm{b}}$ & 0.32 & 0.20 & 3.87 & 3.51 \\
\hline 11 & 89.2 & 85.1 & $1876.2^{\mathrm{a}}$ & $1668.6^{\mathrm{a}}$ & 0.34 & 0.21 & 4.91 & 4.46 \\
\hline 12 & 94.2 & 96.2 & $2193.3^{\mathrm{a}}$ & $1877.6^{\mathrm{a}}$ & 0.36 & 0.24 & 5.78 & 5.02 \\
\hline Total & 532.0 & 517.3 & & & 2.02 & 1.30 & 23.57 & 21.84 \\
\hline
\end{tabular}

a,b Means with the different superscript letters in same row showed significant differences at $(p<0.05)$

Note: Considering the price of local CFD $0.54 \mathrm{USD} / \mathrm{kg}$ and FFD $0.36 \mathrm{USD} / \mathrm{kg}$ and the price for $1 \mathrm{~kg}$ of free-range chicken is $2.8 \mathrm{USD} / \mathrm{kg}$ based local market price in Malaysia. The average live weight was used to determine the price of the free-range chicken.

bird) and (31.0 g/bird and $24.1 \mathrm{~g} / \mathrm{bird})$ for male and female. High fat content in poultry is an unfavorable condition to the farmers due to the choice by the consumers and also an economic disadvantage due to the waste from unused energy from feed that later on been converted to fat (Fouad et al. 2014).

In term of economic factor, free-range chickens fed with FFD diet can develop a profitable business due to its lower cost compared to CFD diet. From this research, the profit and cost for both diets would be increased as the age of the chicken gets older. It is being recommended at 1.5 $\mathrm{kg}$ of weight would be most ideal weight for free-range chicken market, so that farmers can obtain more profit. The calculation was based on feed intake and cost of feed/ $\mathrm{kg}$. The use of local agricultural products such as $\mathrm{CMC}$ and PKC showed potentiality as a replacer to CFD ingredient and can be considered as an economical advantage not just because of their availability in local market and cheaper cost but also due to their nutritive value. However, Table 5 shows the approximate profit based on the two types of diet, where CFD generally more profitable than FFD diet. This is mostly due to the lower body weight recorded for FFD fed chicken. Although FFD cost is lesser (USD 1.30) compared to CFD (USD 2.02) for a chick per cycle, the live body weight of CFD fed chicken were heavier, thus resulting higher profit. Nevertheless, FFD nutritive value such as low abdominal fat still can attract more consumers compared to CFD fed chicken and can result in a profitable business as well as in free-range chicken industry, whereby consumers prefer younger and lower than average weights of normally slaughtered free-range chicken, due to its price and sizeperception of free-range chicken by the local consumers. In addition, more research should be conducted in the near future to improve the body weight of FFD fed chicken, so that it generates higher profit in this agro-business industry.

\section{CONCLUSION}

In summary, the body weight regardless of gender of crossbred free-range chickens showed no significant 
difference between diets. However, male fed with CFD was significantly heavier compared to the chickens fed with FFD. Females fed with FFD showed no significant difference for both 8 and 12 Week of ages. CFD fed male chickens contains significantly high abdominal fat content compared to FFD fed male chickens for 8 and 12 Week of ages. Furthermore, the meat to bone ratio for FFD fed chicken showed no significant difference with CFD fed chicken at Week 12 indicating that FFD chicken could produce good meat production as CFD chicken with lower production of undesirable products such as feathers and bones. Meanwhile, the abdominal fat for CFD and FFD showed no significant difference for female chickens at Week 8 , but CFD was significantly higher in abdominal fat content at Week 12 of age compared with FFD. It is interesting to note that the cost of production for free-range chicken fed with CFD (USD 2.02) was higher compared to FFD fed chicken (USD 1.30). However, CFD recorded more profit compared to FFD fed chicken due the difference body weight at slaughtering age. In a nutshell, it is recommended that Week 12 is the most profitable for selling crossbred free-range chicken for both diets. In conclusion, the use of local feed resources such as PKC and CMC have the potential to replace the use of commercial ingredients in free-range chicken diets, especially in term of cost-benefit.

\section{ACKNOWLEDGEMENTS}

We would like to express our gratitude to the Equitable Society Research Cluster (ESRC), University of Malaya through RP029C-15SBS project. The authors are also grateful to International Halal Research University of Malaya (IHRUM), Animal Biotechnology-Embryo Laboratory (ABEL) University of Malaya members, Livestock Science Centre (LSC), University of Malaya staff and Glami Lemi Biotechnology Research Centre staff.

\section{REFERENCES}

Ahmed, E. \& Azahan, E. 2011. Tracing the growth of crossbred village (kampung) chickens from hatch till maturity. Malaysian Journal of Animal Science 14(1): 1-5.

Alimon, A.R. 2004. The nutritive value of palm kernel cake for animal feed. Palm Oil Deveploment 40(1): 12-14.

Ariff, E.E., Tapsir, S., Sarmin, S. \& Abu, K.A. 2010. Cost and return for local fowl rearing. Economic and Technology Management Review 5: 41-49.

Dzulfazly, A., Dahlan, I., Noraini, S., Azlan, M. \& Rosnizah, I. 2016. Dried coconut flesh as potential feedstuff for ruminants. 37th MSAP Annual Conference. pp. 106-107.

Department of Statistic Malaysia. 2016. Supply and utilization accounts selected agricultural commodities Malaysia 2011-2015. The Office of Chief Statistician Malaysia. http://www.dosm.gov.my/v1/index.php?r=column/ cthemeByCat\&cat $=164 \&$ bul id $=$ L1FGWIV1SWx 5 VWIy ZUpCWjB4NzU1UT09\&menu_id=Z0VTZGU1UHBUT1 VJMFlpaXRRR0xpdz09\#.

Department of Veterinary Service Malaysia. 2017. Semenanjung Malaysia Populasi Ternakan Perangkaan Ternakan 2017/2018. http://www.dvs.gov.my/index.php/ pages/view/2234.
Engku Azahan, E.A., Azlina Azma, I.A. \& Noraziah, M. 2011. Growth response of crossbred village (kampung) chickens to starter diets of differing energy contents. Malaysian Society of Animal Production 14: 51-55.

Fouad, A.M. \& El-Senousey, H.K. 2014. Nutritional factors affecting abdominal fat deposition in poultry: A review. Asian-Australasian Journal of Animal Sciences 27(7): 1057-1068.

International Poultry Council. 2011. Chicken meat per capita consumption for top chicken producing countries. http://www. internationalpoultrycouncil.com/the-world poultryindustry/ statistics/chart/chicken/pe r-capita-consumption-of-poultrymeat. Accessed on 3 March 2017.

Kingori, A.M., Tuitoek, J.K., Muiruri, H.K. \& Wachira, A.M. 2003. Protein requirements of growing indigenous chickens during the 14-21 weeks growing period. South African Journal of Animal Science 33: 78-82.

Khawaja, T., Khan, S.H. \& Ansari, N.N. 2007. Effect of different levels of blood meal on broiler performance during two phases of growth. International Journal of Poultry Science 6(12): 860-865.

Liu, S.K., Niu, Z.Y., Min, Y.N., Wang, Z.P., Zhang, J., He, L. \& Liu, F.Z. 2015. Effects of dietary crude protein on the growth performance, carcass characteristics and serum biochemical indexes of Lueyang black-boned chickens from seven to twelve weeks of age. Revista Brasileira de Ciência Avícola 17(1): 103-108.

Liang, J.B., Fierkens, B., Roch, J.J. \& Engku Azahan, E.A. 1995. Efficiency of metabolisable energy utilisation by commercial broilers and indigenous chickens in Malaysia. MARDI Research Journal 23: 59-62.

Mbajiorgu, C.A., Ng'ambi, J.W. \& Norris, D. 2011. Effect of varying dietary energy to protein ratio level on growth and productivity of indigenous Venda chickens. Asian Journal Animal Veterinar Advances 6(4): 344-352.

Mupeta, B., Wood, J., Mandonga, F. \& Mhlanga, J. 2000. A comparison of the performance of free-range chickens, under improved feed management, with the performance of hybrid chickens in tropical Zimbabwe. In Sustaining Livestock in Challenging Dry Season Environments: Strategies for Smallscale Livestock Farmers, Smith, T. \& Godfrey, S.H. (Eds.). Proceedings of the third workshop on livestock production programme projects. pp. 26-28.

NRC. 1994. Nutrient Requirements of Poultry. 9th Revised Edition. Washington DC, USA: National Academy Press. pp. 19-34.

Oh, B.T. 1987. Malaysia: Economic importance. In Newcastle Disease in Poultry: A New Food Pellet Vaccine, Copland, J.W. (Ed.). Canberra: Australian Centre for International Agricultural Research. pp. 83-85.

Qiao, M., Fletcher, D.L., Smith, D.P. \& Northcutt, J.K. 2001. The effect of broiler breast meat color on $\mathrm{pH}$, moisture, water-holding capacity, and emulsification capacity. Poultry Science 80: 676-680.

Ramlah, A.H. 1996. Performance of village fowl in Malaysia. World's Poultry Science Journal 52(1): 75-79.

Saenphoom, P., Liang, J.B., Ho, Y.W., Loh, T.C. \& Rosfarizan, M. 2013. Effects of enzyme treated palm kernel expeller on metabolizable energy, growth performance, villus height and digesta viscosity in broiler chickens. Asian-Australasian Journal Animal Science 26(4): 537-544.

Saonoah, M.N. 2006. Panduan Penternakan Ayam Kampung. Putrajaya: Ibu Pejabat Jabatan Veterinar. 
Sharmila, A., Alimon, A.R., Azhar, K., Noor, H.M. \& Samsudin, A.A. 2014. Improving nutritional values of palm kernel cake (PKC) as poultry feeds: A review. Malaysian Journal of Animal Science 17(1): 1-18.

Supramaniam, P. 1987. Malaysia: Poultry production. In Newcastle Disease in Poultry: A New Food Pellet Vaccine, Copland, J.W. (Ed.). Canberra: Australian Centre for International Agricultural Research. pp. 81-82.

Tadelle, D., Kijora, C. \& Peters, K.J. 2003. Indigenous chicken ecotypes in Ethiopia: Growth and feed utilization potentials. International Journal of Poultry Science 2: 144-152.

Yulvianti, M., Ernayati, W. \& Tarsono, T. 2015. Pemanfaatan ampas kelapa sebagai bahan baku tepung kelapa tinggi serat dengan metode freeze drying. Jurnal Integrasi Proses 5(2): 101-107.

\section{Mohd Shahmi Hakimi}

Animal Biotechnology-Embryo Laboratory (ABEL)

Institute of Biological Sciences

Universiti Malaya

50603 Kuala Lumpur, Federal Territory

Malaysia

M. Mohd Shahmi Hakimi

Glami Lemi Biotechnology Research Centre University of Malaya

71650 Jelebu, Negeri Sembilan Darul Khusus

Malaysia
Z. Alias*, W.E. Wan Khadijah \& R.B. Abdullah UM Halal Research Center (UMHRC)

Academy of Islamic Studies

Universiti Malaya, 50603 Kuala Lumpur, Federal Territory Malaysia

M.M. Rahman

Faculty of Agro Based Industry

Universiti Malaysia Kelantan, Jeli Campus 17600 Jeli, Kelantan Darul Naim Malaysia

W.E. Wan Khadijah \& R.B. Abdullah

Faculty of Bioresources and Food Industry Universiti Sultan Zainal Abidin, Besut Campus 22200 Besut, Terengganu Darul Iman Malaysia

*Corresponding author; email: alias@um.edu.my

Received: 3 July 2018

Accepted: 25 February 2019 